\title{
THE WONDERFUL WORLD OF WAXCAPS
}

CHRIS HAY email: chris.r.j.hay@gmail.com

The waxcaps are, you guessed it, a group of mushrooms with waxy caps. That is, they feel and look somewhat like wax. Even the gills are thick and have a similar texture. The family for this group is the Hygrophoraceae, comprised of two genera: Hygrocybe and Hygrophorus. Hygrocybe consists of mushrooms with bright, almost fluorescent, shades of red, orange, yellow, and green; Hygrophorus on the other hand is made up of plain grayish tones. Think Kansas in monochrome sepia versus the technicolour land of $\mathrm{Oz}$.

However, recent phylogenetic studies have shown the true relationships in this family are not so fairy tale simple. New genera have been proposed and some reorganizing has been done, ${ }^{1}$ but this hasn't yet trickled down into common usage. The scope of the family has been expanded and now includes, along with the typical waxcaps, some lichens and corticoid (crust) fungi. How interesting that such an assemblage would be more related than other agaric (cap, gills, and stem) fungi! The common thread in the scientific names here is "hygro" which comes from the Greek "hugros" meaning "wet".
Often the cap surface appears shiny or is actually slimy.

Waxcaps are interesting from a conservation perspective. There has been great interest in studying "waxcap grasslands", especially in the United Kingdom since the ' $80 \mathrm{~s}$. From years of research there are now well established survey records and this has allowed for a flourishing of conservation initiatives surrounding these fungi. Ancient grasslands and their distinct fungi have become a treasured part of the ecological heritage across Europe. What are the treasured fungi of Saskatchewan's mixedgrass prairies, I wonder? Old, "unimproved" grasslands such as those found in the Netherlands will have a very different waxcap composition than those where fertilizer has been applied. ${ }^{2}$ With rising demands on natural areas there is increasing concern over protecting them. A grassland assessment system has even been developed, using waxcaps in addition to other mushroom groups common to this ecosystem: Clavarioids (fairy clubs), Hygrocybe sensu lato (the waxcaps), Entolomataceae 
(another largely agaric family), Geoglossaceae (earth tongues), and Dermaloma (more agarics) the CHEGD system. ${ }^{3}$

Within Saskatchewan, waxcaps can be found in a variety of places and sometimes lead to surprising encounters. I have heard several reports (and been sent photos) of single orange to red waxcaps being found within vast grasslands, each individual like a little glowing ember hiding in the wide open field. Sometimes they are even seen sprouting from crevices amidst cliffs where there is some soil. However, like most mushrooms they are also seen in forests, particularly Hygrophorus which are ectomycorrhizal with trees. The true ecology of Hygrocybe is still a mystery - are they saprotrophs? Parasites? Mycorrhizal with grasses or maybe mosses? All of the above? Research has been done in this area, ${ }^{4}$ but the picture isn't clear yet.

Hygrocybe conica is the waxcap I have found most often and that I recommend looking out for. This species (maybe a group of species) is a well known mushroom with the common name "witch's hat". This is fitting not only since the cap shape is conical (like a witch's hat) but since the mushroom is usually deep red. Also, like a curse, it 90 will always transform pitch black with age or after being picked. So your beautiful vibrant specimen turns into a shrivelly black hag. Thoughts come to mind of the red apple and the evil queen from Snow White.

I hope for many waxcap surprise encounters in your future! Perhaps when you see one you will think of how they helped to conserve ancient grasslands half way around the world, wonder at what ecological role they are serving, or remember a fairy tale from your childhood.

\section{References:}

1.Lodge DJ, Padamsee $M$, Matheny PB, Aime MC, Cantrell SA, Boertmann D, . . . Hattori T (2013) Molecular phylogeny, morphology, pigment chemistry and ecology in Hygrophoraceae (Agaricales). Fungal Diversity 64, p. 1-99.

2. Arnolds E (1989) The influence of increased fertilization on the macrofungi of a sheep meadow. Opera Botanica 100, p. 7-21.

3. Rotheroe M, Newton A, Evans S, Feehan J (1996) Waxcapgrassland survey. The Mycologist 10 , p. 23-25.

4. Griffith GW, Graham A, Woods RG, Easton GL, Halbwachs H Blue Jay 
(2014) Effect of biocides on the fruiting of waxcap fungi. Fungal Ecology 7, p. 67-69.

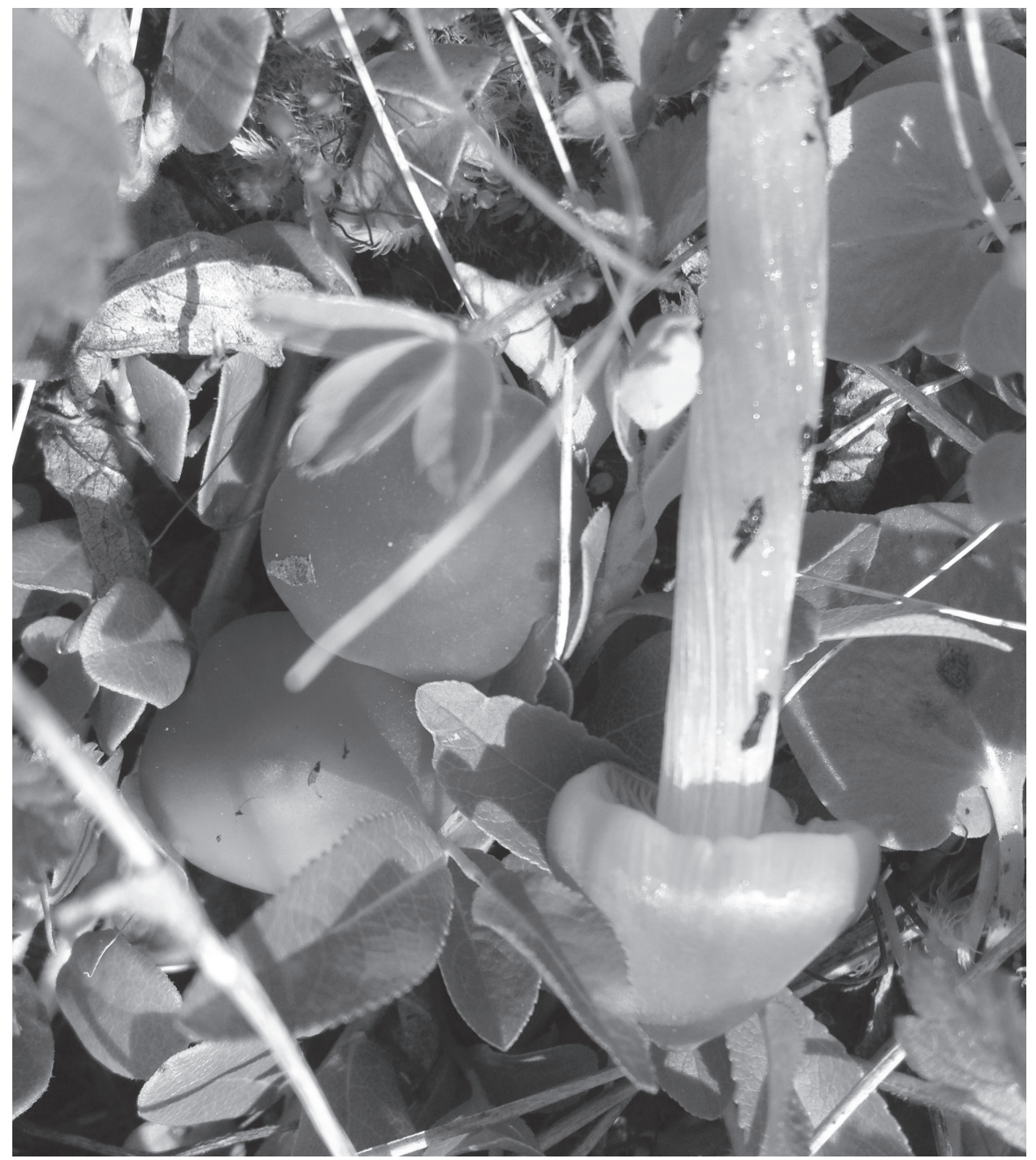

Three fruiting bodies of Hygrocybe conica. The caps are red-to yellowhued (like a ripening apple) and on the uprooted one you can see the thick gills peeking out from under the cap and the naturally twisted yellow stem. The caps are less sharply pointed here, but after picking, the mushroom bruised black and continued blackening until fully dry. [see colour photo on inside back cover]

- Chris Hay 